\title{
ANALISIS SENYAWA ASAM KLOROGENAT DALAM BIJI KOPI ROBUSTA (Coffea canephora) MENGGUNAKAN HPLC
}

\author{
Mentari Yunika Sari ${ }^{1}$, Tati Suhartati ${ }^{1}$, Husniati $^{2}$ \\ ${ }^{1}$ Jurusan Kimia, Fakultas Matematika dan Ilmu Pengetahuan Alam, Universitas Lampung \\ ${ }^{2}$ Balai Riset dan Standarisasi Industri (Baristand), Bandar Lampung \\ mentariyunika@gmail.com
}

\begin{tabular}{|l|}
\hline Artikel Info \\
Diterima \\
tanggal \\
12.09 .2019 \\
Disetujui \\
publikasi \\
tanggal \\
31.10.2019 \\
Kata kunci : \\
Ekstraksi, kopi, \\
kafein, Robusta \\
\end{tabular}

\begin{abstract}
ABSTRAK
Kopi merupakan salah satu komoditas andalan dalam sektor perkebunan Indonesia. Penelitian dan artikel saat ini banyak yang berfokus pada kafein yang terkandung dalam kopi, sedangkan senyawa lain yang bermanfaat seperti asam klorogenat di dalam kopi belum banyak diteliti dan diketahui oleh masyarakat luas. Tujuan dari penelitian ini adalah untuk mengetahui seberapa banyak senyawa asam klorogenat dalam biji tumbuhan kopi Robusta yang mampu terisolasi dengan resin Amberlite ${ }^{\mathrm{TM}}$ FPA900UPS Cl, serta mengetahui kemampuan dan selektifitas resin tersebut dalam mengisolasi senyawa asam klorogenat. Metode ekstraksi menggunakan maserasi dengan pelarut metanol sedangkan untuk pemisahan senyawa menggunakan kromatografi kolom penukar ion dengan eluen buffer sitrat pada berbagai variasi $\mathrm{pH}$. Analisis sampel menggunakan KLT dan HPLC. Hasil yang diperoleh bahwa senyawa asam klorogenat pada fraksi buffer sitrat $\mathrm{pH}$ 6,11 memiliki konsentrasi yang paling tinggi yaitu 27,526 mg/L. Sedangkan resin Amberlite ${ }^{\mathrm{TM}}$ FPA900UPS Cl lebih selektif digunakan untuk pemisahan senyawa kafein dengan konsentrasi
\end{abstract} terekstrak sebesar 345,520 $\mathrm{mg} / \mathrm{L}$.

\begin{abstract}
Coffee is one of the biggest commodities within the Indonesian plantation sector. Current research and articles have focused on caffeine contained in coffee, whereas other useful compounds in coffee such as chlorogenic acid, have not widely research and known to the wider public. The purpose of the study was to find out how much chlorogenic acid compounds in Robusta coffee plant seeds were able to isolate with the Amberlite ${ }^{\mathrm{TM}}$ FPA900UPS $\mathrm{Cl}$ resin, as well as knowing the ability and selectivity of such resin in isolating chlorogenic acid compounds. The extraction method uses maceration with methanol solvent whereas for separation of compounds uses ion exchanger column chromatography with citric buffer eluent at various variations of $\mathrm{pH}$. Analysis of samples using TLC and HPLC. The result obtained that fraction of the chlorogenic acid compound eluted with citrate buffer in $\mathrm{pH} 6.11$ has the highest concentration of $27.526 \mathrm{mg} / \mathrm{L}$. In conclusion, the Amberlite ${ }^{\mathrm{TM}} \mathrm{FPA} 900 \mathrm{UPS} \mathrm{Cl}$ resin is more selectively used for the separation of caffeine compounds with an extracted concentration of 345,520 mg/L.
\end{abstract}

\section{PENDAHULUAN}

Kopi merupakan salah satu minuman yang digemari oleh masyarakat di Indonesia. Selain itu, kopi dijadikan sebagai komoditas andalan dalam sektor perkebunan Indonesia (Chandra dkk., 2013). Tidak hanya di Indonesia saja, banyak masyarakat dunia mengolah kopi menjadi

doi: http://dx.doi.org/10.23960/aec.v4.i2.2019.p86-93

Anal.Environ.Chem.Anal.Environ.Chem. 
minuman bahkan makanan yang berkualitas dan memiliki harga jual yang tinggi. Hal ini diperkuat dengan pernyataan dari Fujioka dan Shibamoto (2008) bahwa kopi meliputi urutan kedua dari semua komoditas pangan yang dikonsumsi dan diperdagangkan di seluruh dunia.

Dua spesies kopi yang sering dibudidayakan dan memberikan nilai ekonomis yaitu Coffea arabica yang dikenal sebagai kopi Arabika dan Coffea canephora atau kopi Robusta. Kopi Arabika dan Robusta memiliki perbedaan diantaranya iklim ideal untuk tumbuh, aspek fisik, dan komposisi kimia (Farah, 2012). Golongan asam pada kopi akan mempengaruhi mutu dan memberikan aroma serta cita rasa yang khas. Asam yang dominan pada biji kopi adalah asam klorogenat yaitu sekitar $8 \%$ pada biji kopi atau 4,5\% pada kopi sangrai. Selama penyangraian sebagian besar asam klorogenat menjadi asam kafeat dan asam kuinat (Yusianto, 2014).

Asam klorogenat dapat melindungi pertumbuhan kopi dari mikroorganisme, serangga dan radiasi UV (Farah, 2012) sedangkan manfaat asam klorogenat bagi kesehatan manusia yaitu sebagai antioksidan, antivirus, hepatoprotektif, dan berperan dalam kegiatan antispasmodik (Farah dan Carmen, 2006). Banyaknya penelitian dan artikel yang berfokus pada kafein yang terkandung dalam kopi, sedangkan senyawa lain yang bermanfaat seperti asam klorogenat di dalam kopi belum banyak diteliti dan diketahui oleh masyarakat luas. Selain itu, adanya aktivitas senyawa asam klorogenat pada biji kopi yang dapat menghasilkan efek farmakologi dijadikan sebagai dasar penelitian ini.

\section{METODE}

\section{Alat dan Bahan}

Alat utama yang digunakan dalam penelitian ini adalah kolom kromatografi yang berbahan gelas dan instrument analisis HPLC. Bahan yang digunakan adalah kopi hijau, metanol, etil asetat, heksan, buffer sitrat, akuaDM, dan Resin Amberlite FPA900 UPS Cl.

\section{Prosedur}

100 gram serbuk kopi diekstraksi dengan metode perebusan dalam $800 \mathrm{~mL}$ pelarut akuaDM selama 30 menit pada suhu $95^{\circ} \mathrm{C}$. Pemisahan senyawa berdasarkan tingkat kepolarannya dilakukan menggunakan metode partisi atau ekstraksi cair-cair, cara ini dilakukan

doi: http://dx.doi.org/10.23960/aec.v4.i2.2019.p86-93

Anal.Environ.Chem.Anal.Environ.Chem. 
dalam corong pisah. Metode ini didasarkan pada sifat kelarutan komponen target dan distribusinya dalam dua pelarut yang tidak saling campur, yaitu menggunakan pelarut etil asetas dan heksana. Kemudian pemurnian dilakukan menggunakan kolom kromatografi dengan fasa diam Amberlite FPA900 UPS Cl dan dielusi menggunakan buffer sitrat. Masing-masing fraksi hasil kromatografi kolom di KLT dan di analisis dengan HPLC.

\section{HASIL DAN PEMBAHASAN}

\section{Ekstraksi dan Partisi}

Ekstrak hasil perebusan tampak berwarna coklat kehijauan yang mengindikasikan bahwa terdapat senyawa organik yang terlarut dalam pelarut akuademin. Senyawa asam klorogenat merupakan senyawa yang bersifat polar sehingga untuk mendapatkan senyawa yang diinginkan diperlukan pelarut yang memiliki kepolaran yang sesuai seperti akuademin dan metanol. Hasil pemekatan filtrat rebusan kemudian ditimbang dan diperoleh ekstrak kasar (crude extract) biji kopi robusta sebanyak 30,0465 gram yang berwarna kuning kecoklatan.

Ekstrak kasar sebanyak 15,5125 gram dilarutkan dalam $100 \mathrm{~mL}$ metanol (polar) dan dipartisi menggunakan 3x70 mL $n$-heksana (non-polar). Pelarut $n$-heksana digunakan karena memiliki perbedaan kepolaran dengan metanol sehingga senyawa-senyawa non-polar akan tertarik pada pelarut $n$-heksana. Faksi $n$-heksana kemudian dipekatkan dan diperoleh berat sebesar 3,0096 gram sedangkan fraksi metanol yang telah dipisahkan sebanyak 118 mL. Fraksi metanol dipartisi lebih lanjut menggunakan pelarut yang memiliki kepolaran lebih rendah dibawahnya seperti etil asetat, sehingga senyawa yang memiliki kepolaran lebih tinggi akan tetap tertinggal dalam fraksi metanol. Partisi dilakukan dengan penambahan 3x70 mL etil asetat, karena pemisahan tidak terlihat dengan jelas maka ditambahkan 47,2 mL akuades (40\% dari volume fraksi metanol). Diperoleh bobot sebesar 9,5612 gram ekstrak biji kopi robusta.

\section{Pemisahan Asam Klorogenat dari Ekstrak Kasar Biji Kopi Robusta}

Kromatografi kolom dilakukan untuk memisahkan suatu komponen dari campuran dengan cara mengalirkan eluen (fasa gerak) terhadap sampel dalam suatu kolom kaca yang berisi fasa diam. Kromatografi kolom dapat dilakukan dengan berbagai cara, salah satunya secara ionik. 


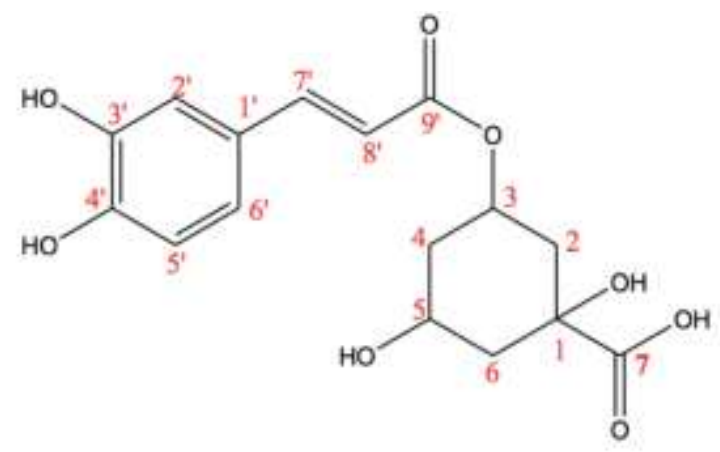

Gambar 1. Struktur asam klorogenat (Sukohar et al., 2011)

Kromatografi kolom penukar ion merupakan salah satu metode yang cocok digunakan untuk pemisahan ion-ion baik berupa kation maupun anion. Seperti yang dapat dilihat pada Gambar 1, senyawa asam klorogenat memiliki gugus karboksil (-COOH) pada posisi 1 yang mana dapat melepaskan proton dan membentuk ion karboksilat. Pemurnian menggunakan kromatografi kolom penukar anion, yaitu anion karboksilat akan melakukan pertukaran dengan anion $\mathrm{Cl}^{-}$yang terdapat dalam fasa diam. Fasa diam yang digunakan adalah resin Amberlite ${ }^{\mathrm{TM}}$ FPA900UPS Cl yang diperoleh dari The Dow Chemical Company, resin ini memiliki ukuran partikel yang seragam $(640 \pm 50 \mu \mathrm{m})$ dan matriksnya berupa copolymer-stirena-divinilbenzen (co-stirena-DVB). Struktur co-stirena-DVB tersusun dari cross-linked senyawa stirena yang terpolimerisasi sehingga $c o$-stirena-DVB dapat digunakan sebagai media adsorbsi dalam berbagai jenis senyawa organik.

Penelitian telah dilakukan pada biji kopi robusta dari berbagai daerah dan dapat ditentukan bahwa asam klorogenat yang terkandung didalamnya memiliki rata-rata $\mathrm{pH}$ sebesar 5,77 (Farhaty \& Muchtaridi, 2014). Sehingga fasa gerak yang digunakan adalah buffer sitrat karna memiliki range $\mathrm{pH}$ yang sesuai dengan asam klorogenat yaitu pH 3,0-6,2; pKa 6,4 (Ruzin, 1999). Asam klorogenat yang telah terikat didalam resin kemudian dielusi menggunakan akuades lalu dilanjutkan dengan buffer sitrat dengan variasi $\mathrm{pH} 6,11 ; 5,18$; dan 4,16. Elusi dengan akuades menghasilkan lima fraksi (A1-A5), fraksi A1 berwarna keruh sedangkan fraksi lain tidak berwarna. Sedangkan elusi menggunakan larutan buffer sitrat pH 6,11 menghasilkan 16 
fraksi (B6.1-B6.16), buffer sitrat pH 5,18 menghasilkan 10 fraksi (B5.1-B5.10), dan buffer sitrat pH 4,16 menghasilkan 10 fraksi (B4.1-B4.10).

\section{Analisis dengan Kromatografi Lapis Tipis (KLT)}

Keempat fraksi hasil partisi, dianalisis KLT untuk mengetahui keberadaan senyawa asam klorogenat yang terdapat dalam masing-masing fraksi. Uji KLT menggunakan plat silika gel dan sistem campuran eluen 10\% asam asetat glasial dalam metanol, kemudian pola yang terbentuk dibandingkan dengan pola standar asam klorogenat (nilai Rf 0,57). Fraksi air yang bersifat polar teridentifikasi mengandung senyawa asam klorogenat pada nilai $\mathrm{Rf} 0,46$, namun masih terdapat senyawa polar lain yang muncul pada hasil KLT dengan Rf 0,22. Sedangkan pada fraksi buffer sitrat $\mathrm{pH} 6,11 ; 5,18$; dan 4,16 teridentifikasi adanya senyawa asam klorogenat pada nilai $\mathrm{Rf}$ yang sama yaitu 0,43. Jarak migrasi senyawa pada plat silika gel tergantung pada polaritasnya. Senyawa yang paling polar bergerak naik dengan jarak paling dekat dari titik awal penotolan, sedangkan senyawa dengan polaritas paling kecil bergerak paling jauh dari titik awal penotolan tersebut.

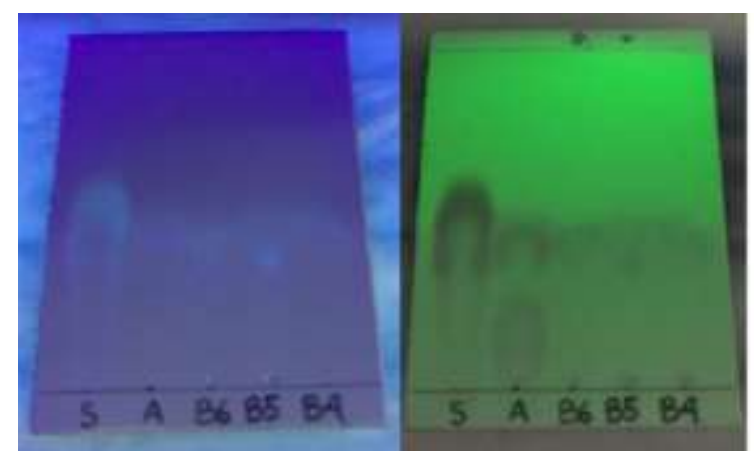

S : Standar asam klorogenat

A : Fraksi air

B6 : Fraksi buffer sitrat pH 6,11

B5 : Fraksi buffer sitrat pH 5,18

B4 : Fraksi buffer sitrat pH 4,16

Gambar 2. Hasil analisis KLT fraksi air dan buffer sitrat pH 6,11; 5,18; dan 4,16

Hasil uji KLT pada setiap fraksi membuktikan bahwa senyawa yang bersifat polar akan terbawa dalam pelarut polar yaitu metanol. Pada fraksi buffer, ketiganya kurang menunjukkan pola yang jelas, hal ini dapat disebabkan oleh pemilihan fasa diam dan fasa gerak yang belum tepat. Oleh sebab itu, dalam penentuan kadar asam klorogenat pada setiap fraksi hasil kromatografi kolom akan diteliti lebih lanjut menggunakan analisis kuantitatif dengan HPLC. Fraksi yang memiliki kadar paling tinggi akan dapat dimurnikan lebih lanjut. 


\section{Analisis dengan High Performance Liquid Chromatodraphy (HPLC)}

(a)

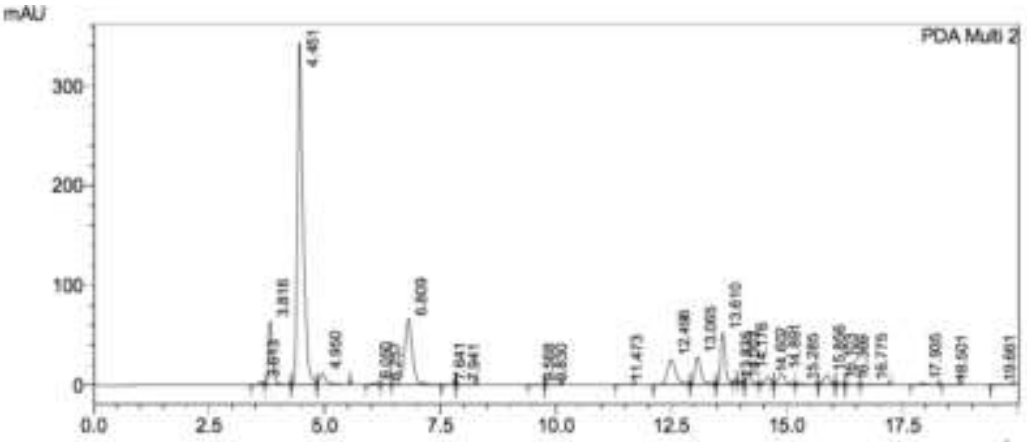

(b)

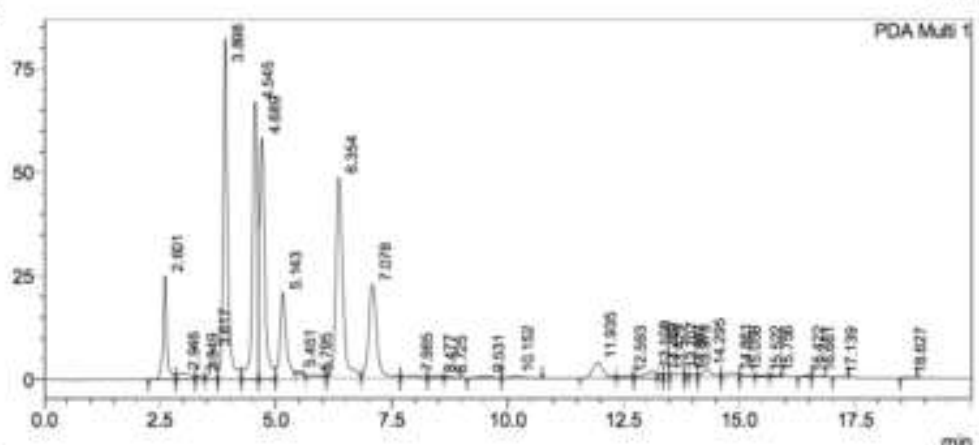

(c) $\mathrm{man}$

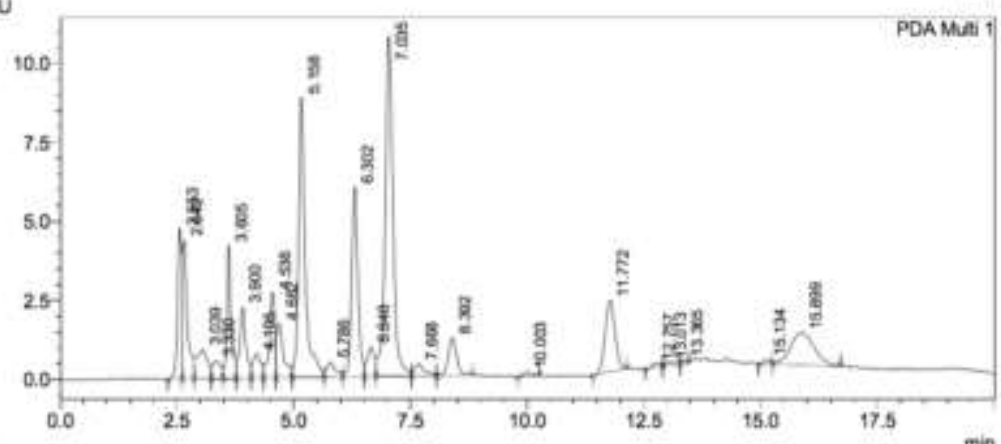

(d)

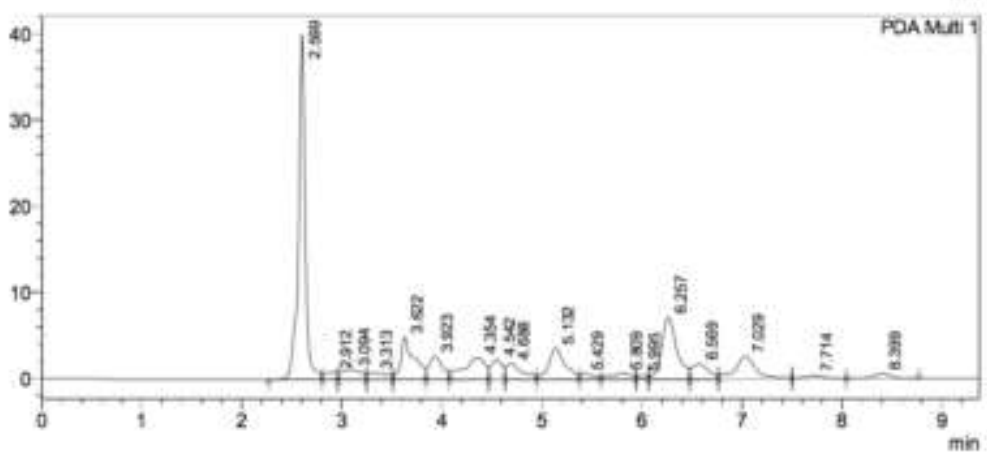

Gambar 3. Kromatogram HPLC untuk (a) fraksi A; (b) fraksi B6; (c) fraksi B5; (d) fraksi B4.

doi: http://dx.doi.org/10.23960/aec.v4.i2.2019.p86-93 
Tingkat kemurnian fraksi air dan buffer sitrat pada setiap variasi $\mathrm{pH}$ dianalisis menggunakan HPLC dengan kolom ODS C-18, detektor Photo Dioda Aray (PDA) dengan fasa gerak akuades : asetonitril (4:1). Standar asam klorogenat sebelumnya telah analisa dan menunjukkan puncak serapan pada waktu retensi 4,456 menit. Hasil analisis fraksi A menunjukkan dua puncak serapan pada waktu retensi 4,550 menit (asam klorogenat) dan 5,154 menit (kafein). Sedangkan pada fraksi B6, B5, dan B4 menunjukkan adanya puncak kecil yang melebar pada masing-masing waktu retensi 4,545 menit, 4,545 menit, dan 4,537 menit.

Setiap fraksi B6, B5, dan B4 juga dibandingkan dengan standar kafein, dan masingmasing menunjukkan puncak serapan pada waktu retensi 5,143 menit; 5,132 menit; dan 5,158 menit. Terbentuknya puncak serapan selain asam klorogenat pada masing-masing fraksi, mengidentifikasikan bahwa senyawa diperoleh belum murni dan perlu dilakukan pemurnian lebih lanjut. Bentuk kromatogram HPLC keempat senyawa dapat dilihat pada Gambar 3.

\section{KESIMPULAN}

Ekstraksi asam klorogenat dari biji tumbuhan kopi robusta (Coffea canephora) menggunakan resin Amberlite ${ }^{\mathrm{TM}}$ FPA900UPS Cl diperoleh ekstrak asar (crude extract) biji kopi robusta yang terdapat di Provinsi Lampung mengandung senyawa asam klorogenat sebesar 49,803 mg/L. Senyawa asam klorogenat pada fraksi buffer sitrat $\mathrm{pH}$ 6,11 memiliki konsentrasi yang paling tinggi yaitu $27,526 \mathrm{mg} / \mathrm{L}$. Resin Amberlite ${ }^{\mathrm{TM}}$ FPA900UPS $\mathrm{Cl}$ lebih selektif digunakan untuk pemisahan senyawa kafein dengan konsentrasi terekstrak sebesar 345,520 $\mathrm{mg} / \mathrm{L}$.

\section{UCAPAN TERIMA KASIH}

Penelitian ini didukung oleh Kementrian Perindustrian Indonesia dan Balai Riset dan Standarisasi Industri Bandar Lampung. 


\section{DAFTAR PUSTAKA}

Chandra, Devi., R. Hanung Ismono, Eka Kasymir. 2013. Prospek Perdagangan Kopi Robusta Indonesia di Pasar Internasional. JIIA, 1(1).

Farah, Adriana. 2012. Coffee : Emerging Health Effect and Disease Prevention, First Edition. John Willey \& Sons, Inc. and Institute of Food Technologists (USA) : Wiley Blackwell Publishing Ltd.

Farah, A. dan Carmen M.D. 2006. Phenolic Compounds in Cofee. Braz. J. Plant. Physiology. $18(1): 23-36$.

Farhaty, N. Dan Muchtaridi, M. 2014. Tinjauan Kimia dan Aspek Farmakologi Senyawa Asam Klorogenat pada Biji Kopi. Jurnal Farmaka. 14(1) : 214-227.

Fujioka, K., dan T. Shibamoto. 2008. Chlorogenic Acid and Caffeine Contents in Various Comercial Brewes Coffes. Food Chemistry, 106 : 217-221.

Fukuda, M., Takahashi, H., dan Konishi, A. 2012. Method of Producing Chlorogenic Compositition. U.S. Patent. Patent No. US 8.309.150 B2.

Sukohar, A., Setiawan, Wirakusumah, F., \& Sastramihardja, H. (2011). Isolation And Characterization Cytotoxic Compounds Caffeine And Chlorogenic Acid. Jurnal Medika Planta, 1(4), 11.

Yusianto, D.N. 2014. Mutu Fisik dan Citarasa Kopi Arabika yang Disimpan Buahnya Sebelum di- Pulping. Pelita Perkebunan : 30(20) : 137-158. 